А. Н. Масюк

Днепропетровский национальный университет им. Олеся Гончара

\title{
ОЦЕНКА СОСТОЯНИЯ НАСАЖДЕНИЙ \\ РОБИНИИ ЛЖЕАКАЦИИ НА РЕКУЛЬТИВИРОВАННЫХ ЗЕМЛЯХ СЕМЕНОВСКО-ГОЛОВКОВСКОГО БУРОУГОЛЬНОГО РАЗРЕЗА
}

\begin{abstract}
Наведено оцінку стану насаджень робінії звичайної, що вирощується в різних лісорослинних умовах, штучно створених на рекультивованих землях Семенівсько-Головківського буровугільного розрізу. Встановлено, що на початкових стадіях розвитку чисті та змішані насадження розвиваються на рівні третього класу бонітету, а починаючи з 15-25 років виходять на рівень першого.
\end{abstract}

A. N. Masyuk

Oles' Gonchar Dnipropetrovsk National University

\section{ESTIMATION OF ROBINIA PSEUDOACACIA PLANTATIONS IN THE RECULTIVATED LANDSCAPS OF SEMENOVSKY-GOLOVKOVSKY BROWN COAL BASIN}

It had been estimated the state of Robina pseudoacacia plantations growing under the various forest conditions, which were created artificially in the recultivated landscapes of Semenovsky-Golovkovsky brown coal basin. It was found that at starting development stages the "pure" and combined plantations grown up to the third growth class, but after 15-25 years they approach the first growth class level.

\section{Введение}

Семеновско-Головковский буроугольный разрез находится в границах Кировоградской группы Днепровского бассейна и расположен в Александрийском районе на водоразделе р. Ингулец и р. Бешка. Он представляет собой отработанный карьер, на дневную поверхность которого вынесены горные породы надугольной толщи. Вскрышные породы представлены лессовидными, красно-бурыми и глауконитсодержащими суглинками, кварцевыми, глауконитсодержащими и углистыми песками, каолиновыми и углистыми глинами, которые становятся объектами рекультивации. Общая площадь рекультивированных земель разреза состоянием на 2005 год составила 1006 га, из них под сельскохозяйственными угодьями - $39 \%$ территории, пастбищами $-2 \%$ и под лесной рекультивацией $-59 \%$.

Состав, свойства, естественное зарастание и пригодность вскрышных горных пород для сельскохозяйственного использования исследовались Г. А. Бондарь [1], Э. Л. Додатко [4], Л. В. Етеревской [5], Е. Желева [6], Zipper [16], Sobek [15], Brenner [11] и другими авторами. Лесопригодность местообитаний отвалов и подбор ассортимента древесных и кустарниковых пород для их облесения изучался В. Н. Данько [3], Е. В. Перцевым [9], Dunker, Barnhisel [14], Schaaf [13]. В результате исследований был установлен ассортимент деревьев и кустарников из 35 видов, пригодных для лесной рекультивации в районах открытой добычи бурого угля. Для каждой рекомендуемой

(C) A. Н. Масюк, 2008

86 
породы указаны природная зона и диапазон местообитаний на отвалах, в пределах которых ее целесообразно использовать. Кроме того, особо отмечалось введение в культуру древесных пород азотонакопителей.

На территории Семеновско-Головковского буроугольного разреза после биологического этапа рекультивации древесно-кустарниковая растительность представлена сосновыми, лоховыми, белоакациевыми, дубовыми фитоценозами, которые находились как в чистом, так и в смешанном состоянии. Они сформировались за счет искусственного выращивания этих культур.

Цель наших исследований - оценить состояние насаждений робинии лжеакации (Robinia pseudoacacia L.), возделываемых в разных лесорастительных условиях, возникших после добычи бурого угля и технического этапа рекультивации.

\section{Материал и методы исследований}

Объекты исследований - насаждения робинии лжеакации, культивируемые на отвалах Семеновско-Головковского буроугольного разреза. В качестве эдафотопа выступали вскрышные горные породы разного гранулометрического состава и происхождения. Своеобразие их определяется нетипичностью, азональностью, а также эдафической неоднородностью, что в совокупности с техногенным расчленением рельефа создает множество вариантов лесорастительных условий. Было заложено 15 пробных площадей (ПП) в Александрийском лесничестве (кварталы 78, 79, 80, 120, 121), отличающихся возрастом (5-25 лет), составом древостоя (чистые и смешанные), составом горных пород (вовлекались отложения неогенного и антропогенного периодов - суглинистого (СГ), глинистого (Г), песчаного (П) гранулометрического состава), состоянием увлажненности и привязанностью к разным элементам рельефа. Обследование осуществлялось в соответствии с требованиями лесной таксации [11], методическими указаниями [2; 7] и техническими условиями [10]. Лесотаксационные показатели древостоя определялись по нормативно-справочным материалам [8].

\section{Результаты и их обсуждение}

Насаждения робинии лжеакации на техноземах занимают 150,6 га, что составляет $27 \%$ от всей лесорекультивированной площади разреза. Эта культура благодаря своим биологическим особенностям и экологическим потребностям рекомендована для разнофункционального применения при восстановлении нарушенных земель.

В изученных белоакациевых насаждениях наблюдается большое разнообразие в пространственном строении фитоценозов, зависящих от пестроты лесорастительных условий. Влияние антропогенного фактора наблюдается на всей территории разреза и проявляется в техногенном образовании рельефа, переформировании отвалов, выносе на дневную поверхность вскрышных горных пород надугольной толщи. Возвышения чередуются с понижениями, что обусловливает пестроту почвенного покрова как по плодородию, так и по увлажненности (табл.).

Наибольшую площадь занимают чистые 25 -летние насаждения робинии ПП-4 и ПП-1, находящиеся в понижении и представленные суглинистыми отложениями, в которых встречаются примеси глин, песка и бурого угля. Диапазон увлажнения может варьировать от влажных до мокрых $\left(\mathrm{C}_{3-5}\right)$. В таких лесорастительных условиях высота древостоя составила соответственно 11-12 м, диаметр - 12-14 см, запасы древесины - 83-96 м³/га, полнота - 0,8, что позволяет отнести их к I-Іа классу бонитета. Средний прирост за год на ПП-4-3,32 м³, на ПП-1 - 3,84 м². Такие отличия связаны с на- 
личием в эдафотопе ПП-4 большего количества включений углистой глины и меньшей его увлажненностью.

На СГ 2 в 20-летнем возрасте белая акация (ПП-5) при полноте 0,8 имеет запас стволовой древесины $83 \mathrm{~m}^{3} /$ га (среднегодовой прирост составил 4,15 м³). В этом возрасте достигается максимальный лесорастительный эффект белой акации на рекультивированных землях, выраженный в показателях среднего прироста.

Лесотаксационная характеристика насаждений робинии лжеакации

Таблища

\begin{tabular}{|c|c|c|c|c|c|c|c|}
\hline $\begin{array}{l}\text { Пробная } \\
\text { площадь }\end{array}$ & $\begin{array}{c}\text { Состав } \\
\text { древостоя }\end{array}$ & $\begin{array}{c}\text { Возраст, } \\
\text { лет }\end{array}$ & $\begin{array}{c}\text { Высота, } \\
\text { м } \\
\end{array}$ & $\begin{array}{c}\text { Диаметр, } \\
\text { см } \\
\end{array}$ & $\begin{array}{c}\text { Класс } \\
\text { бонитета } \\
\end{array}$ & $\begin{array}{l}\text { Пол- } \\
\text { нота }\end{array}$ & $\begin{array}{c}\text { Запас древе- } \\
\text { сины, м³/га }\end{array}$ \\
\hline ПП-8 & 10АКБ+КЛЯ & 5 & 3 & 4 & III & 0,70 & 6 \\
\hline ПП-14 & 10АКБ & 8 & 3 & 4 & III & 0,70 & 6 \\
\hline ПП-9 & 7АКБЗКЛЯ & 10 & 4 & 4 & III & 0,60 & 9 \\
\hline ПП-10 & 10АКБ+ТК & 10 & 4 & 6 & III & 0,80 & 11 \\
\hline ПП-11 & 7АКБЗКЛЯ & 10 & 4 & 4 & III & 0,70 & 11 \\
\hline ПП-12 & 6АКБ4С3 & 11 & 4 & 6 & II & 0,70 & 12 \\
\hline ПП-13 & 10АКБ & 11 & 6 & 8 & Ia & 0,85 & 28 \\
\hline ПП-2 & 10АКБ & 12 & 6 & 8 & $\mathrm{Ia}$ & 0,80 & 26 \\
\hline ПП-15 & 10АКБ & 12 & 6 & 8 & Ia & 0,75 & 25 \\
\hline ПП-6 & 10АКБ & 13 & 6 & 8 & $\mathrm{I}$ & 0,75 & 25 \\
\hline ПП-7 & 10АКБ & 13 & 6 & 8 & $\mathrm{I}$ & 0,75 & 25 \\
\hline ПП-3 & 10АКБ & 15 & 8 & 10 & $\mathrm{Ia}$ & 0,75 & 44 \\
\hline ПП-5 & 10АКБ & 20 & 11 & 12 & Іб & 0,80 & 83 \\
\hline ПП-4 & 10АКБ & 25 & 11 & 12 & $\mathrm{I}$ & 0,80 & 83 \\
\hline ПП-1 & 10АКБ & 25 & 12 & 14 & Ia & 0,80 & 96 \\
\hline
\end{tabular}

Пробная площадь 3 заложена в 15-летних насаждениях в тальвеге отвала на суглинистых породах во влажно-мокрых условиях увлажнения $\left(\mathrm{C \Gamma}_{3-5}\right)$ и была окружена крутыми склонами (до $40^{\circ}$ ) юго-западной и северо-восточной экспозиций. Древостой имел среднюю высоту 8 м, средний диаметр -10 см, запасы древесины $-44 \mathrm{~m}^{3} / \mathrm{ra}$; при плотности 0,75 он относится к Іа классу бонитета. Средний прирост составил $2,98 \mathrm{~m}^{3}$.

На пробных площадях 2, 6, 7, 13, 15 насаждения имели возраст 11-13 лет. Они отличались условиями произрастания, показатели которых варьировали по гранулометрическому составу (от легких суглинков до средних глин с включениями углевмещающих пород) и положению относительно рельефа (от плато до склонов разной экспозиции и угла наклона). В данном возрасте в таком широком диапазоне лесорастительных условий древостой достигает высоты 6 м и диаметра 8 см, полнота варьирует от 0,75 до 0,85 , что приводит к дифференциации запасов древесины $\left(25-28 \mathrm{~m}^{3} /\right.$ га) и колебанию среднего прироста (от 1,92 до 2,55 м³). Формирование древостоя идет по пути I-Іа класса бонитета.

Восьмилетние насаждения (ПП-14) располагались на склоне восточной экспозиции и отличались самыми низкими лесотаксационными показателями: высота -3 м, диаметр - 4 см, запас древесины $-6 \mathrm{~m}^{3} / г$, полнота $-0,7$, средний прирост $-0,75 \mathrm{~m}^{3}$. Древостой относится к III классу бонитета.

Таким образом, на начальных стадиях развития (до 10 лет) чистые белоакациевые насаждения соответствуют III классу бонитета. С возрастом происходит повышение лесотаксационных показателей до уровня I, Іа, Іб бонитетов. Рассматривая темпы роста древостоя, следует отметить, что показатели среднего прироста достигают максималь-

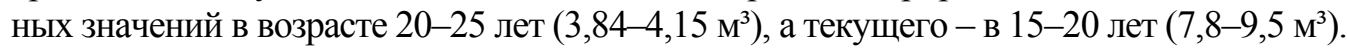


Смешанные насаждения занимают площадь 58 га, из которых на сосновобелоакациевые приходится 47 \% территории, на кленово-белоакациевые - 33 \% и натополево-белоакациевые - 20 \%. Насаждение с составом древостоя 6АКБ4СО формировалось в верхней трети отвала западной экспозиции на суглинистых отложениях. Развитие его в 11-летнем возрасте соответствует II классу бонитета. Запасы древесины

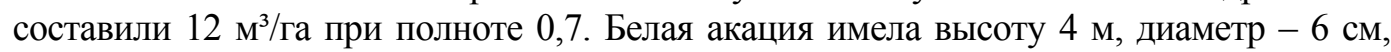
сосна (Pinus sylvestris L.) соответственно 3 и 4.

Десятилетнее насаждение с составом древостоя 10АКБ+ТК относится к III классу бонитета. При полноте 0,8 накапливает $11 \mathrm{~m}^{3} /$ га стволовой древесины. Средняя высота робинии составляет 4 м, диаметр - 6 см, тополя (Populus deltoides Marsh.) - соответственно 5 м и 8 см.

Пробные площади 9 и 11 имели одинаковый состав (7АКБЗКЛЯ) и возраст (10 лет), но отличались лесорастительными условиями, что привело к изменению лесотаксационных показателей. ПП-9 размещалась на сильносмытых грунтах, подверженных водной линейной эрозии. ПП-11 располагалась на выровненной платообразной поверхности. При равных показателях высоты и диаметра различия наблюдались в полноте (соответственно 0,6 и 0,7), что повлияло на запасы древесины (9 и 11 м³/га). Данные насаждения относятся к III классу бонитета.

Состав древостоя на ПП-8 (10АКБ+КЛЯ) в 5-летнем возрасте соответствовал III классу бонитета. Насаждения размещались на сильносмытых суглинисто-глинистых горных породах, подверженных водной линейной эрозии. Высота белой акации -3 м, диаметр - 4 см, для клена ясенелистного (Acer negundo L.) эти показатели составили соответственно 4 м и 6 см. Запасы древесины 6 м³/га.

Таким образом, чистые насаждения робинии лжеакации на рекультивированных землях Семеновско-Головковского буроугольного разреза имели более высокие показатели высоты, диаметра и продуктивности; в возрастном диапазоне 5-11 лет они превышали на этой стадии ход роста и запасы древесины смешанных насаждений.

\section{Выводы}

На рекультивированных землях на первых этапах их биологического освоения сильно заторможены процессы саморегуляции и восстановления плодородия, что значительно снижает устойчивость белоакациевых фитоценозов (как чистых, так и смешанных) к условиям, предоставляемым им средой. С возрастом происходит повышение лесотаксационных показателей от III до уровня I, Іа, Іб классов бонитетов. Сравнение запасов стволовой древесины робинии лжеакации показало превосходство чистых насаждений над смешанными клено-белоакациевыми, сосново-белоакациевыми и тополево-белоакациевыми древостоями. Одним из путей повышения продуктивности белоакациевых насаждений является повышение полноты от $0,60-0,75$ до $0,85-0,90$, что обеспечит увеличение запасов древесины на 30-35 \%.

\section{Библиографические ссылки}

1. Бондарь Г. А. Сингенетические сукцессии растительного покрова на породах надугольной толщи Александрийского буроугольного месторождения / Г. А. Бондарь, Э. Л. Додатко // Рекультивация земель. Труды Днепропетр. СХИ. - Д.: ДСХИ, 1974. - Т. 26. - С. 50-61.

2. Гордиенко М. И. Методические указания по изучению и исследованию лесных культур. К.: УCXA, 1979. $-90 \mathrm{c}$. 
3. Данько В. Н. Лесопригодность местообитаний и ассортимент древесных и кустарниковых пород для их облесения // Рекультивация земель, нарушенных при добыче полезных ископаемых. Тез. докл. координационного совещ. - Тарту, 1975. - С. 25-30.

4. Додатко Э. Л. Химико-минералогический состав пород Семеновско-Головковского буроугольного карьера // Почвоведение. - 1972. - № 1. - С. 86-95.

5. Етеревская Л. В. Почвообразование и рекультивация земель в техногенных ландшафтах Украины. Дисс. ... Д-ра с.-х. наук: 06.01.03. - Харьков, 1989. - 42 с.

6. Желева Е. Некоторые аспекты почвообразовательного процесса на рекультивированных отвалах в угледобывающем районе «Марица Восток» // Биологическая рекультивация земель. Матер. Междунар. совещ. - Екатеринбург: УрО РАН, 2003. - С. 93-103.

7. Кобранов Н. П. Обследование и исследование лесных культур. Учебное пособие для студентов лесохозяйственного факультета (специальность 1512). - Л.: ЛТА, 1973. - 76 с.

8. Нормативно-справочные материалы для таксации лесов Украины и Молдавии / А. З. Швыденко, Ю. Н. Савич, А. А. Строчинский и др. - К.: Урожай, 1987. - 559 с.

9. Перцев Е. В. Лесная рекультивация земель, нарушенных при добыче бурого угля и марганцевой руды открытым способом (на примере правобережной лесостепи и степи УССР). Автореф. дисс. ... канд. с.-х. наук: 06.03.01 / УкрНИИЛХА. - Харьков, 1981. - 20 с.

10. Технические указания по проведению инвентаризации лесных культур, защитных лесных насаждений, питомников, площадей с проведенными мерами содействия естественному возобновлению леса и вводу молодняков в категорию ценных древесных насаждений. - М.: ВНИИЦлесресурс, 1990. - 78 с.

11. Усольцев В. А. Методы определения биологической продуктивности насаждений / В. А. Усольцев, С. В. Залесов. - Екатеринбург: Урал. гос. лесотехн. ун-т, 2005. - 147 с.

12. Brenner F. Wildlife and fishery consideration in surface mine reclamation // In R. I. Barnhisel et al. Reclamation drastically disturbed lands / Agron. Monogr. Vol. 41. - WI: ASA, CSSA and Madison, 2000. - P. 399-414.

13. Development of element cycles at post-mining sites / W. Schaaf, M. Gast, R. Wilden, R. F. Huettl // First Intern. Conf. Soil of Urban, Industrial, Traffic and Mining Areas. - University of Essen, 2000. - Vol. 3. - P. 1015-1021.

14. Dunker R. E. Cropland reclamation / R. E. Dunker, R. I. Barnhisel // In R. I. Barnhisel et al. Reclamation drastically disturbed lands / Agron. Monogr. Vol. 41. - WI: ASA, CSSA and Madison, 2000. - P. 323-370.

15. Sobek A. Chemical and physical properties of overburden and menesoils / A. Sobek, J. G. Skousen, S. E. Jr. Fisher // In R. I. Barnhisel et al. Reclamation drastically disturbed lands. / Agron. Monogr. Vol. 41. - WI: ASA, CSSA and Madison, 2000. - P. 77-104.

16. Zipper C. E. Coal main reclamation, acid mine drainage and the Clean Water Act // In R. I. Barnhisel et al. Reclamation drastically disturbed lands. Agron. Monogr. 41. - WI: ASA, CSSA and Madison, 2000. - P. 169-192.

Надійшла до редколегії 14.07.2008 